\title{
Synthesis, crystal structure, thermal analysis and dielectric properties of two mixed trichlorocadmiates (II)
}

\author{
ABDESSATTAR BEN CHRIFA*, ABDELHAMID BEN SALAH and MOHAMED LOUKIL \\ Laboratoire des Sciences des Matériaux et d'Environnement, Faculté des Sciences de Sfax, Université de Sfax, \\ BP 1171, Route de Soukra, 3018 Sfax, Tunisia
}

MS received 5 October 2015; accepted 9 March 2016

\begin{abstract}
K}_{0.57}\left(\mathrm{NH}_{4}\right)_{0.43} \mathrm{CdCl}_{3}$ and $\mathrm{K}_{0.25}\left(\mathrm{NH}_{4}\right)_{0.75} \mathrm{CdCl}_{3}$ are orthorhombic, space group Pnma, $Z=4$, with $a=$ 8.8760(4) $\AA, b=3.9941(2) \AA, c=14.7004(7) \AA$, and $Z=4, a=8.9567(9) \AA, b=3.9957(4) \AA ⿻ 丿$,$c=14.855(2) \AA$, respectively. Final $R$ values are 0.01 and 0.02 for 608 and 834 reflections, respectively. In both the materials, the crystal structure has been determined by $\mathrm{X}$-ray single crystal analysis at room temperature ( $293 \mathrm{~K}$ ). The compound structures consist of $\mathrm{K}^{+}\left(\right.$or $\mathrm{NH}_{4}^{+}$) cations and double chains of $\mathrm{CdCl}_{6}$ octahedra sharing one edge extending along $b$-axis. The mixture of $\mathrm{K}^{+} / \mathrm{NH}_{4}^{+}$cations are located between the double chains ensuring the stability of the structure by ionic and hydrogen bonding contacts N/K-H. . . Cl. Spectroscopic, dielectric and differential scanning calorimetry (DSC) measurements were performed to discuss the mechanism of the phase transition. These studies show that these materials, $\mathrm{K}_{0.57}\left(\mathrm{NH}_{4}\right)_{0.43} \mathrm{CdCl}_{3}$ and $\mathrm{K}_{0.25}\left(\mathrm{NH}_{4}\right)_{0.75} \mathrm{CdCl}_{3}$, undergo a phase transition at 438 and $454 \mathrm{~K}$, respectively.
\end{abstract}

Keywords. X-ray diffraction; dielectric study; phase transition; DSC; IR absorption; Raman scattering.

\section{Introduction}

The compounds of general formula $\mathrm{ABX}_{3}$ (A being alkali, $\mathrm{B}, \mathrm{Hg}$ or $\mathrm{Cd}$ and $\mathrm{X}$, a halide ion), undergo structural phase transitions and interesting physical properties such as ferroelectricity [1-4]. Their structures are slightly distorted from ideal perovskite-type structures [5,6]. Its phase transitions have been intensively studied using Landau theory and lattice dynamics analysis. These systems include the well-defined and extensive class of hexagonal magnetic $\mathrm{ABX}_{3}$ compounds in which $A$ and $B$ are cations and $X$ is a halogen ion [7-9]. In fact, most $\mathrm{ABX}_{3}$ compounds are quasi-one-dimensional magnets [10].

Crystalline $\mathrm{KCdCl}_{3}$ consists of double chains of regular octahedra $\mathrm{CdCl}_{6}$ sharing edges [11], with two short $\mathrm{Cd}-\mathrm{Cl}$ bond lengths and always close to the sum of the covalent radii, the additional four $\mathrm{Cl}$ atoms are significantly further away, but at a distance which is less than the sum of the Vander Waals radii. To examine the effect and the influence of cationic substitution over symmetry and physical properties, we have extended these investigations to $\mathrm{K}_{0.57}\left(\mathrm{NH}_{4}\right)_{0.43} \mathrm{CdCl}_{3}$ and $\mathrm{K}_{0.25}\left(\mathrm{NH}_{4}\right)_{0.75} \mathrm{CdCl}_{3}$.

In the present study, we report and discuss the results of a structural investigation, concerning new solid solutions: $\mathrm{K}_{0.57}\left(\mathrm{NH}_{4}\right)_{0.43} \mathrm{CdCl}_{3}$ and $\mathrm{K}_{0.25}\left(\mathrm{NH}_{4}\right)_{0.75} \mathrm{CdCl}_{3}$. We have performed preliminary X-ray diffraction (XRD) measurements providing information about the complete crystal structure at room temperature of the new compounds. These materials were examined by electrical properties, infrared (IR) and

*Author for correspondence (abdessattarbenchrifa@yahoo.fr)
Raman vibrational spectroscopies and differential scanning calorimetry (DSC) thermal technique. The aim of the present work is to determine the title compounds' phase transitions.

\section{Experimental}

\subsection{Synthesis}

The crystals of $\mathrm{K}_{0.57}\left(\mathrm{NH}_{4}\right)_{0.43} \mathrm{CdCl}_{3}$ and $\mathrm{K}_{0.25}\left(\mathrm{NH}_{4}\right)_{0.75} \mathrm{CdCl}_{3}$ were synthesized dissolving a mixture of $\mathrm{KCl}, \mathrm{NH}_{4} \mathrm{Cl}$ and $\mathrm{CdCl}_{2} \cdot \mathrm{H}_{2} \mathrm{O}$ in aqueous solution:

$x \mathrm{KCl}+(1-x) \mathrm{NH}_{4} \mathrm{Cl}+\mathrm{CdCl}_{2} \cdot \mathrm{H}_{2} \mathrm{O} \stackrel{\mathrm{H}_{2} \mathrm{O}}{\longrightarrow} \mathrm{K}_{x}\left(\mathrm{NH}_{4}\right)_{(1-x)} \mathrm{CdCl}_{3}$.

Colourless single crystals were obtained by cooling the mixture for 15 days. The composition of the compound was determined by chemical analysis and density measurements.

\section{$2.2 X$-ray structure determination}

Two transparent parallelepipedic crystals with dimensions, $0.20 \times 0.12 \times 0.04$ and $0.26 \times 0.14 \times 0.12$, were chosen from the preparation. The intensity data were collected on An APEX II diffractometer with graphite-crystal monochromated $\mathrm{MoK} \alpha$ radiation $(0.71073 \AA)$. Lorentz and polarizing effect corrections were carried out before the refinement. Data collection procedure and structure refinement at room temperature are given in table 1.

The cadmium positions were determined using a threedimensional Patterson synthesis. Chlorine, nitrogen and potassium atoms were located by three-dimensional Fourier 
Table 1. Crystal structure data and experimental conditions of the structure determination of $\mathrm{K}_{0.57}\left(\mathrm{NH}_{4}\right)_{0.43} \mathrm{CdCl}_{3}$ and $\mathrm{K}_{0.25}\left(\mathrm{NH}_{4}\right)_{0.75} \mathrm{CdCl}_{3}$.

\begin{tabular}{|c|c|c|}
\hline Summary of crystallographic data & $T=293(2) \mathrm{K}$ & $T=293(2) \mathrm{K}$ \\
\hline Formula & $\mathrm{K}_{0.57}\left(\mathrm{NH}_{4}\right)_{0.43} \mathrm{CdCl}_{3}$ & $\mathrm{~K}_{0.25}\left(\mathrm{NH}_{4}\right)_{0.75} \mathrm{CdCl}_{3}$ \\
\hline Formula weight & 217.97 & 118.71 \\
\hline Space group & Pnma & Pnma \\
\hline$a(\AA)$ & $8.876(4)$ & $8.9567(9)$ \\
\hline$b(\AA)$ & $3.9941(2)$ & $3.9957(4)$ \\
\hline$c(\AA)$ & $14.7004(7)$ & $14.855(2)$ \\
\hline$V\left(\AA^{3}\right)$ & $521.15(4)$ & $531.64(9)$ \\
\hline Z & 4 & 4 \\
\hline$\rho_{\text {calc }}\left(\mathrm{g} \mathrm{cm}^{-3}\right)$ & 2.778 & 2.966 \\
\hline$\mu\left(\mathrm{mm}^{-1}\right)$ & 5.343 & 5.723 \\
\hline Crystal size $\left(\mathrm{mm}^{3}\right)$ & $0.22 \times 0.14 \times 0.06$ & $0.28 \times 0.16 \times 0.10$ \\
\hline Crystal shape & Parallelepipedic & Parallelepipedic \\
\hline$F(000)$ & 400 & 436 \\
\hline Data collection instrument & Kappa-APEX II & Kappa-APEX II \\
\hline Radiation, graphite monochromator & $\lambda_{\mathrm{K} \alpha \mathrm{Mo}}(0.71073 \AA)$ & $\lambda_{\mathrm{K} \alpha \mathrm{Mo}}(0.71073 \AA)$ \\
\hline$\theta$ range for data collection $\left(^{\circ}\right)$ & $3.60-26.40$ & $2.66-30.03$ \\
\hline \multirow[t]{3}{*}{ Index ranges } & $-11 \leq h \leq 10$ & $-12 \leq h \leq 12$ \\
\hline & $-4 \leq k \leq 4$ & $-4<k<2$ \\
\hline & $-17 \leq 1 \leq 18$ & $-10 \leq 1 \leq 20$ \\
\hline Total reflections & 608 & 834 \\
\hline Reflection with $(F>4 \sigma(F))$ & 580 & 760 \\
\hline$R(F)^{\mathrm{a}}(\%)$ & 0.01 & 0.02 \\
\hline$W R_{2}^{\mathrm{b}}(\%)$ & 0.04 & 0.07 \\
\hline$R_{\text {int }}-R_{\sigma}$ & $0.01-0.02$ & $0.03-0.02$ \\
\hline CCDC diposit number* & 1050833 & 1050820 \\
\hline
\end{tabular}

*For more details: http://www.ccdc.cam.ac.uk/conts/retrieving.html or e-mail: deposit@ccdc.cam.ac.uk. ${ }^{\mathrm{a}} R=\sum\left\|F_{\mathrm{O}}|-| F_{\mathrm{C}}\right\| / \sum\left|F_{\mathrm{O}}\right| \cdot{ }^{\mathrm{b}} W R_{2}=\left[\frac{\sum\left[w\left(\left|F_{\mathrm{O}}\right|^{2}-\left|F_{\mathrm{C}}\right|^{2}\right)\right]^{2}}{\sum\left[w\left(\left|F_{\mathrm{O}}\right|^{2}\right)\right]^{2}}\right]^{1 / 2}$.

Table 2. Fractional atomic and equivalent thermal parameters.

\begin{tabular}{|c|c|c|c|c|c|c|}
\hline Atoms & $x$ & $y$ & $z$ & $U_{\mathrm{eq}}$ & Occupation & Sites \\
\hline \multicolumn{7}{|c|}{$\mathrm{K}_{0.57}\left(\mathrm{NH}_{4}\right)_{0.43} \mathrm{CdCl}_{3}$} \\
\hline $\mathrm{Cd}$ & $0.16919(3)$ & $1 / 4$ & $0.056108(2)$ & $0.02099(1)$ & 1 & $2 d$ \\
\hline $\mathrm{K}$ & $0.57125(1)$ & $-1 / 4$ & $0.17631(8)$ & $0.0274(5)$ & $0.568(6)$ & $2 d$ \\
\hline $\mathrm{N}$ & $0.57125(1)$ & $-1 / 4$ & $0.17631(8)$ & $0.0274(5)$ & $0.432(7)$ & $2 d$ \\
\hline $\mathrm{H} 1$ & $0.6166(7)$ & $-0.0534(7)$ & $0.1884(8)$ & 0.033 & 1 & $1 d$ \\
\hline $\mathrm{H} 2$ & $0.549(3)$ & $-1 / 4$ & $0.1166(4)$ & 0.033 & 1 & $2 d$ \\
\hline H3 & $0.4831(1)$ & $-1 / 4$ & $0.2067(2)$ & 0.033 & 1 & $2 d$ \\
\hline $\mathrm{Cl1}$ & $0.28833(1)$ & $1 / 4$ & $0.21039(6)$ & $0.0256(2)$ & 1 & $2 d$ \\
\hline $\mathrm{Cl} 2$ & $0.02344(9)$ & $1 / 4$ & $-0.10149(5)$ & $0.02005(2)$ & 1 & $2 d$ \\
\hline $\mathrm{Cl} 3$ & $0.33271(9)$ & $-1 / 4$ & $-0.00735(6)$ & $0.0226(2)$ & 1 & $2 d$ \\
\hline \multicolumn{7}{|c|}{$\mathrm{K}_{0.25}\left(\mathrm{NH}_{4}\right)_{0.75} \mathrm{CdCl}_{3}$} \\
\hline $\mathrm{Cd}$ & $0.16702(3)$ & $3 / 4$ & $0.943568(2)$ & $0.02007(2)$ & 1 & $2 d$ \\
\hline $\mathrm{Cl1}$ & $0.33101(9)$ & $1 / 4$ & $1.00534(6)$ & $0.0209(2)$ & 1 & $2 d$ \\
\hline $\mathrm{Cl} 2$ & $0.02455(1)$ & $3 / 4$ & $1.10065(5)$ & $0.0192(2)$ & 1 & $2 d$ \\
\hline $\mathrm{Cl} 3$ & $0.28492(1)$ & $3 / 4$ & $0.79011(6)$ & $0.0246(2)$ & 1 & $2 d$ \\
\hline $\mathrm{K}$ & $0.0689(2)$ & $1 / 4$ & $0.67525(1)$ & $0.0285(7)$ & $0.253(7)$ & $2 d$ \\
\hline $\mathrm{N}$ & $0.0689(2)$ & $1 / 4$ & $0.67525(1)$ & $0.0285(7)$ & $0.747(7)$ & $2 d$ \\
\hline $\mathrm{H} 1$ & $-0.0213(1)$ & $1 / 4$ & $0.702(2)$ & 0.034 & 1 & $2 d$ \\
\hline $\mathrm{H} 2$ & $0.138(2)$ & $1 / 4$ & $0.7195(1)$ & 0.034 & 1 & $2 d$ \\
\hline $\mathrm{H} 3$ & $0.0778(1)$ & $0.0535(7)$ & $0.6461(3)$ & 0.034 & 1 & $1 d$ \\
\hline
\end{tabular}

$U_{\text {eq }}=1 / 3 \sum_{i} \sum_{j} U_{i j} a *_{i} a *_{j} a_{i} a_{j}$. 
Table 3. Anisotropic displacement parameters (in $10^{-3} \AA^{2}$ ).

\begin{tabular}{lllllll}
\hline Atoms & $\mathrm{U} 11$ & $\mathrm{U} 22$ & $\mathrm{U} 33$ & $\mathrm{U} 23$ & $\mathrm{U} 13$ & $\mathrm{U} 12$ \\
\hline $\mathrm{K}_{0.57}\left(\mathrm{NH}_{4}\right)_{0.43} \mathrm{CdCl}_{3}$ & & & & & \\
$\mathrm{Cd}$ & $0.02351(2)$ & $0.01688(2)$ & $0.02261(2)$ & 0 & $-0.00411(9)$ & 0 \\
$\mathrm{~K}$ & $0.0321(7)$ & $0.0212(7)$ & $0.0287(7)$ & 0 & $-0.0013(5)$ & 0 \\
$\mathrm{~N}$ & $0.0321(7)$ & $0.0212(7)$ & $0.0287(7)$ & 0 & $-0.0013(5)$ & 0 \\
$\mathrm{Cl} 1$ & $0.0290(5)$ & $0.0239(5)$ & $0.0238(4)$ & 0 & $-0.0054(3)$ & 0 \\
$\mathrm{Cl} 2$ & $0.0209(4)$ & $0.0199(4)$ & $0.0193(4)$ & 0 & $-0.0009(3)$ & 0 \\
$\mathrm{Cl} 3$ & $0.0207(4)$ & $0.0174(4)$ & $0.0295(4)$ & 0 & $0.0032(3)$ & 0 \\
$\mathrm{~K}_{0.25}\left(\mathrm{NH}_{4}\right)_{0.75} \mathrm{CdCl}_{3}$ & & & & & \\
$\mathrm{Cd}$ & $0.0241(2)$ & $0.0152(3)$ & $0.0209(2)$ & 0 & $0.00373(8)$ & 0 \\
$\mathrm{Cl} 1$ & $0.0213(4)$ & $0.0155(5)$ & $0.0261(4)$ & 0 & $-0.0031(8)$ & 0 \\
$\mathrm{Cl} 2$ & $0.0220(4)$ & $0.0186(5)$ & $0.0171(4)$ & 0 & $0.0009(3)$ & 0 \\
$\mathrm{Cl} 3$ & $0.0296(5)$ & $0.0226(5)$ & $0.0217(4)$ & 0 & $0.0043(3)$ & 0 \\
$\mathrm{~K}$ & $0.035(1)$ & $0.0200(1)$ & $0.0305(1)$ & 0 & $-0.0027(8)$ & 0 \\
$\mathrm{~N}$ & $0.035(1)$ & $0.02(1)$ & $0.0305(1)$ & 0 & $-0.0027(8)$ & 0 \\
\hline
\end{tabular}

Table 4. Principal interatomic distances $(\AA)$ and bond angles $\left({ }^{\circ}\right)$ in $\mathrm{CdCl}_{6}$ octahedra.

\begin{tabular}{|c|c|c|c|c|c|c|c|}
\hline \multicolumn{4}{|c|}{$\mathrm{K}_{0.57}\left(\mathrm{NH}_{4}\right)_{0.43} \mathrm{CdCl}_{3}$} & \multicolumn{4}{|c|}{$\mathrm{K}_{0.25}\left(\mathrm{NH}_{4}\right)_{0.75} \mathrm{CdCl}_{3}$} \\
\hline $\mathrm{Cd}-\mathrm{Cl1}$ & $2.5025(9)$ & & & $\mathrm{Cd}-\mathrm{Cl} 3$ & $2.5123(9)$ & & \\
\hline $\mathrm{Cd}^{\mathrm{i}}-\mathrm{Cl}^{\mathrm{i}}$ & $2.6391(6)$ & & & $\mathrm{Cd}-\mathrm{Cl} 1^{\mathrm{i}}$ & $2.6440(6)$ & & \\
\hline $\mathrm{Cd}-\mathrm{Cl} 2$ & $2.6534(8)$ & & & $\mathrm{Cd}-\mathrm{Cl} 2$ & $2.6597(9)$ & & \\
\hline $\mathrm{Cd}-\mathrm{C} 12^{\mathrm{ii}}$ & $2.7123(6)$ & & & $\mathrm{Cd}-\mathrm{Cl} 2^{\mathrm{x}}$ & $2.7142(6)$ & & \\
\hline $\mathrm{Cd}-\mathrm{K}^{\mathrm{iii}}$ & $4.1208(1)$ & & & $\mathrm{Cd}-\mathrm{K}^{\mathrm{xi}}$ & $4.176(2)$ & & \\
\hline $\mathrm{K}-\mathrm{Cl} 1^{\text {iv }}$ & $3.2365(1)$ & & & $\mathrm{K}-\mathrm{Cl} 3^{\mathrm{v}}$ & $3.2628(2)$ & & \\
\hline $\mathrm{K}-\mathrm{Cl1} 1^{\mathrm{v}}$ & $3.2474(1)$ & & & $\mathrm{K}-\mathrm{Cl} 3^{\mathrm{xii}}$ & $3.2754(2)$ & & \\
\hline $\mathrm{K}-\mathrm{Cl} 3^{\mathrm{iii}}$ & $3.2991(1)$ & & & $\mathrm{K}-\mathrm{Cl1}{ }^{\mathrm{xiii}}$ & $3.3415(2)$ & & \\
\hline $\mathrm{K}-\mathrm{Cl} 2^{\mathrm{vi}}$ & $3.3728(1)$ & & & $\mathrm{K}-\mathrm{Cl1} 1^{\mathrm{xiv}}$ & $3.3415(2)$ & & \\
\hline $\mathrm{K}-\mathrm{Cl} 3$ & $3.4310(1)$ & & & $\mathrm{K}-\mathrm{Cl1}{ }^{\mathrm{xii}}$ & 3. $426(2)$ & & \\
\hline $\mathrm{K}-\mathrm{Cl} 2^{\mathrm{iii}}$ & $3.7619(1)$ & & & $\mathrm{K}-\mathrm{Cl} 2^{\mathrm{xv}}$ & 3. $433(2)$ & & \\
\hline $\mathrm{K}-\mathrm{K}^{\mathrm{vii}}$ & $3.9941(2)$ & & & $\mathrm{K}-\mathrm{K}^{\mathrm{vii}}$ & $3.9957(4)$ & & \\
\hline $\mathrm{K}-\mathrm{Cd}^{\mathrm{iii}}$ & $4.1208(1)$ & & & $\mathrm{K}-\mathrm{Cd} \mathrm{d}^{\mathrm{iii}}$ & $4.176(2)$ & & \\
\hline $\mathrm{K}-\mathrm{H} 1$ & $0.8999(1)$ & & & $\mathrm{K}-\mathrm{H} 1$ & $0.9(1)$ & & \\
\hline $\mathrm{K}-\mathrm{H} 2$ & $0.9(1)$ & & & $\mathrm{K}-\mathrm{H} 2$ & $0.8999(1)$ & & \\
\hline $\mathrm{K}-\mathrm{H} 3$ & $0.9(1)$ & & & $\mathrm{K}-\mathrm{H} 3$ & $0.8999(1)$ & & \\
\hline $\mathrm{Cl} 1-\mathrm{K}^{\mathrm{viii}}$ & $3.2365(1)$ & & & $\mathrm{Cl} 2-\mathrm{K}^{\mathrm{xv}}$ & $3.433(2)$ & & \\
\hline $\mathrm{Cl} 2-\mathrm{K}^{\mathrm{ix}}$ & $3.2991(1)$ & & & & & & \\
\hline \multicolumn{4}{|c|}{$\mathrm{K}_{0.57}\left(\mathrm{NH}_{4}\right)_{0.43} \mathrm{CdCl}_{3}$} & \multicolumn{4}{|c|}{$\mathrm{K}_{0.25}\left(\mathrm{NH}_{4}\right)_{0.75} \mathrm{CdCl}_{3}$} \\
\hline $\mathrm{Cl1}$ & $\mathrm{Cd} 1$ & $\mathrm{Cl} 3^{\mathrm{i}}$ & $95.04(2)$ & $\mathrm{Cl} 3$ & $\mathrm{Cd} 1$ & $\mathrm{Cl} 1^{\mathrm{i}}$ & $94.67(3)$ \\
\hline $\mathrm{Cl}^{\mathrm{i}}$ & $\mathrm{Cd} 1$ & $\mathrm{Cl} 3$ & $98.35(3)$ & $\mathrm{Cl} 1^{\mathrm{i}}$ & $\mathrm{Cd} 1$ & $\mathrm{Cl1}$ & $98.16(3)$ \\
\hline $\mathrm{Cl1}$ & $\mathrm{Cd} 1$ & $\mathrm{Cl} 2$ & $175.82(3)$ & $\mathrm{Cl} 3$ & $\mathrm{Cd} 1$ & $\mathrm{Cl} 2$ & $176.18(3)$ \\
\hline $\mathrm{Cl}^{\mathrm{i}}$ & $\mathrm{Cd} 1$ & $\mathrm{Cl} 2$ & $87.68(2)$ & $\mathrm{Cl}^{\mathrm{i}}$ & $\mathrm{Cd} 1$ & $\mathrm{Cl} 2$ & $87.82(2)$ \\
\hline $\mathrm{Cl} 1$ & $\mathrm{Cd} 1$ & $\mathrm{Cl} 2^{\mathrm{ii}}$ & $92.49(2)$ & $\mathrm{Cl} 3$ & $\mathrm{Cd} 1$ & $\mathrm{Cl} 2^{\mathrm{ii}}$ & $92.64(3)$ \\
\hline $\mathrm{Cl}^{\mathrm{i}}$ & $\mathrm{Cd} 1$ & $\mathrm{Cl} 2^{\mathrm{ii}}$ & $172.22(3)$ & $\mathrm{Cl} 1^{\mathrm{i}}$ & $\mathrm{Cd} 1$ & $\mathrm{Cl} 2^{\mathrm{ii}}$ & $172.46(3)$ \\
\hline $\mathrm{Cl} 3$ & $\mathrm{Cd} 1$ & $\mathrm{Cl} 2^{\mathrm{ii}}$ & $82.904(2)$ & $\mathrm{Cl} 1$ & $\mathrm{Cd} 1$ & $\mathrm{Cl} 2^{\mathrm{ii}}$ & $83.05(2)$ \\
\hline $\mathrm{Cl} 2$ & $\mathrm{Cd} 1$ & $\mathrm{Cl} 2^{\mathrm{ii}}$ & $84.69(2)$ & $\mathrm{Cl} 2$ & $\mathrm{Cd} 1$ & $\mathrm{Cl} 2^{\mathrm{ii}}$ & $84.78(2)$ \\
\hline $\mathrm{Cl1}$ & $\mathrm{Cd} 1$ & $\mathrm{Cl} 2^{\mathrm{iii}}$ & $92.49(2)$ & $\mathrm{Cl} 3$ & $\mathrm{Cd} 1$ & $\mathrm{Cl} 2^{\mathrm{vi}}$ & $92.64(3)$ \\
\hline $\mathrm{Cl} 2^{\mathrm{ii}}$ & $\mathrm{Cd} 1$ & $\mathrm{Cl} 2^{\mathrm{iii}}$ & $94.83(3)$ & $\mathrm{Cl} 2^{\mathrm{i}}$ & $\mathrm{Cd} 1$ & $\mathrm{Cl} 2^{\mathrm{vi}}$ & $94.79(3)$ \\
\hline
\end{tabular}

Symmetry codes: (i) $x . y+1 . z$; (ii) $-x .-y .-z$; (iii) $-x+1 .-y .-z$; (iv) $x+1 / 2 . y-1$. $-z+1 / 2$; (v) $x . y-1 . z$; (vi) $-x+1 / 2 .-y \cdot z+1 / 2$; (vii) $-x .-y+1 .-z$; (viii) $x-1 / 2 . y$. $-z-1 / 2$; (ix) $-x+1 .-y-1 .-z ;(x)-x .-y+1 .-z+2 ;$ (xi) $-x+1 / 2 . y+1 / 2 .-z+1 / 2$; (xii) $x-1 / 2 . y+1 / 2 .-z+1 / 2$; (xiii) $-x+1 / 2 . y-1 / 2 . z-1 / 2$; (xiv) $-x+1 / 2 . y-1 / 2$. $z-1 / 2 ;(\mathrm{xv})-x+1 .-y+1 .-z+2$.

Symmetry codes: (i) $x . y+1 . z$; (ii) $-x .-y .-z$; (iii) $-x .-y+1 .-z$; (iv) $-x .-y+2 .-z+2$. 
function. The $\mathrm{H}$ atoms were located geometrically, and attributed isotropic thermal factors equal to those of the atoms on which they are linked. Structure solution and refinement were carried out using SHELXS and SHELXL programmes $[12,13]$. The nonhydrogen atoms were refined anisotropically. The final atomic coordinates are given in table 2. Main geometrical features, bond distances and angles are reported in tables 3 and 4 .

Interatomic distances, bond angles and details of the hydrogen bonding scheme are given in table 5 .

\section{$2.3 D S C$}

DSC measurements were carried out using a DSC 822P METTLER TOLEDO calorimeter. DSC was recorded in $340-460 \mathrm{~K}$ regions at a heating rate of $5 \mathrm{~K} \mathrm{~min}^{-1}$ using a polycrystalline sample in a flowing nitrogen atmosphere.

\subsection{IR spectrum}

For the IR measurement, a small quantity of the powder was used. The IR spectrum was recorded at room temperature in $400-4000 \mathrm{~cm}^{-1}$ region using a $\mathrm{KBr}$ pellet on Perkin Elmer spectrometer. The spectral resolution was $1 \mathrm{~cm}^{-1}$.

\subsection{Raman spectra}

Raman spectra were measured with a LABRAMHR 800 triple monochromator. Raman spectra were recorded in $50-3500 \mathrm{~cm}^{-1}$ region.

\subsection{Dielectric studies}

Polycrystalline pellets, $12 \mathrm{~mm}$ in diameter and $1 \mathrm{~mm}$ in thickness, were obtained at room temperature by pressing under $200 \mathrm{MPa}$. In the electrical measurement, the sample

Table 5. Principal interatomic distances $(\AA)$ and bond angles $\left({ }^{\circ}\right)$ involved in the hydrogen bonds.

\begin{tabular}{|c|c|c|c|c|}
\hline & $\mathrm{N}-\mathrm{H}$ & H. . .Cl & N/K...H. .Cl & $\mathrm{N} / \mathrm{K} \ldots \mathrm{Cl}$ \\
\hline \multicolumn{5}{|c|}{$\mathrm{K}_{0.25}\left(\mathrm{NH}_{4}\right)_{0.75} \mathrm{CdCl}_{3}$} \\
\hline $\mathrm{N}-\mathrm{H} 1 \ldots \mathrm{Cl} 1^{\mathrm{i}}$ & 0.9 & 2.451 & 146.03 & 3.236 \\
\hline $\mathrm{N}-\mathrm{H} 2 \ldots \mathrm{Cl} 3$ & 0.9 & 2.646 & 146.24 & 3.431 \\
\hline $\mathrm{N}-\mathrm{H} 2 \ldots \mathrm{Cl} 3^{\mathrm{ii}}$ & 0.9 & 2.77 & 118.82 & 3.299 \\
\hline $\mathrm{N}-\mathrm{H} 3 \ldots \mathrm{Cl} 1^{\mathrm{iii}}$ & 0.9 & 2.642 & 125.4 & 3.247 \\
\hline $\mathrm{N}-\mathrm{H} 3 \ldots \mathrm{Cl} 2^{\mathrm{iv}}$ & 0.9 & 2.822 & 120.83 & 3.373 \\
\hline \multicolumn{5}{|c|}{$\mathrm{K}_{0.57}\left(\mathrm{NH}_{4}\right)_{0.43} \mathrm{CdCl}_{3}$} \\
\hline $\mathrm{N}-\mathrm{H} 1 \ldots \mathrm{Cl} 3^{\mathrm{v}}$ & 0.9 & 2.649 & 127.44 & 3.275 \\
\hline $\mathrm{N}-\mathrm{H} 1 \ldots \mathrm{Cl} 2^{\mathrm{vi}}$ & 0.9 & 2.933 & 116.70 & 3.433 \\
\hline $\mathrm{N}-\mathrm{H} 2 \ldots \mathrm{Cl} 3^{\mathrm{iii}}$ & 0.9 & 2.614 & 129.63 & 3.263 \\
\hline $\mathrm{N}-\mathrm{H} 3 \ldots \mathrm{Cl} 1^{\mathrm{vii}}$ & 0.9 & 2.552 & 146.79 & 3.341 \\
\hline
\end{tabular}

Symmetry codes: (i) $x+1 / 2, y,-z+1 / 2$; (ii) $-x+1,-y-1,-z$; (iii) $x, y-1, z$; (iv) $-x+1 / 2,-y, z+1 / 2$; (v) $x-1 / 2,-y+1 / 2,-z+3 / 2$; (vi) $-x,-y+1,-z+2$; (vii) $-x+1 / 2, y-1 / 2, z-1 / 2$. was pasted with $\mathrm{Ag}$ on the two sample faces, as the electrodes with Ni paste or sputtered Au make amalgams with cadmium compounds.

\section{Results and discussion}

\subsection{Structure of $\mathrm{K}_{x}\left(\mathrm{NH}_{4}\right)_{(1-x)} \mathrm{CdCl}_{3}$ description}

The crystal structure of $\mathrm{K}_{0.57}\left(\mathrm{NH}_{4}\right)_{0.43} \mathrm{CdCl}_{3}$ is depicted in figure 1.

At room temperature, $\mathrm{K}_{0.57}\left(\mathrm{NH}_{4}\right)_{0.43} \mathrm{CdCl}_{3}$ is orthorhombic. The space group is Pnma, the unit cell dimensions are $a=8.8760$ (4) $\AA, b=3.9941(2) \AA, c=14.7004(7) \AA$ and $Z=4$. It consists of double chain of $\mathrm{CdCl}_{6}$ octahedra running along the $b$-axis (figure 2). Each $\mathrm{Cd}-\mathrm{Cl}$ bond ranges from $2.5025(9)$ to $2.7123(6) \AA$ (figure $4 \mathrm{~b}$ ). The $\mathrm{Cl}-\mathrm{Cd}-\mathrm{Cl}$ angles extend from 82.903(19) to $175.82(3)^{\circ}$ (table 4).

The $\mathrm{K}^{+}$or $\mathrm{NH}_{4}^{+}$tetrahedra reside in the 2(d) site of the orthorhombic cell. The presence of $\mathrm{NH}_{4}^{+}$cations induces the

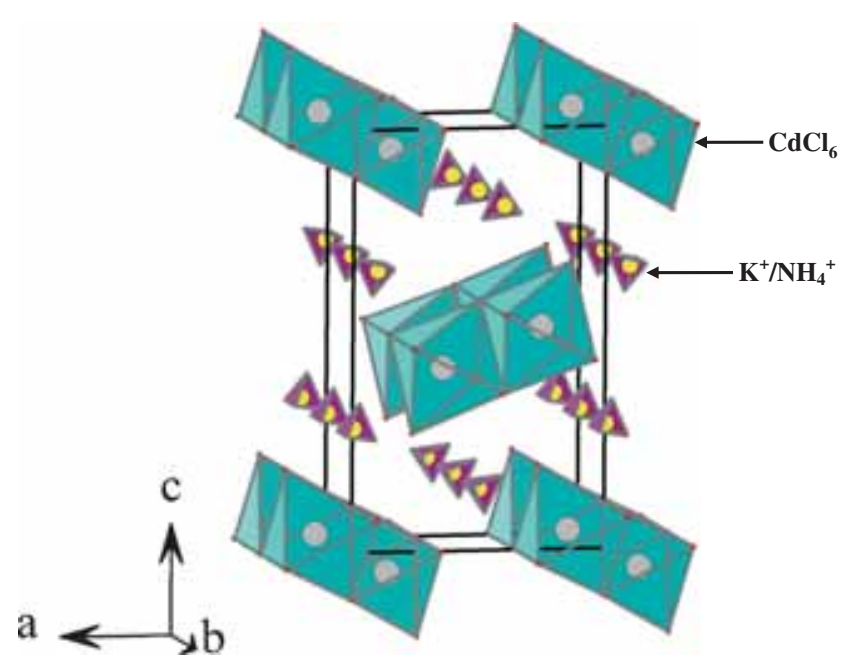

Figure 1. Perspective view of the structure of $\mathrm{K}_{0.57}\left(\mathrm{NH}_{4}\right)_{0.43} \mathrm{CdCl}_{3}$.

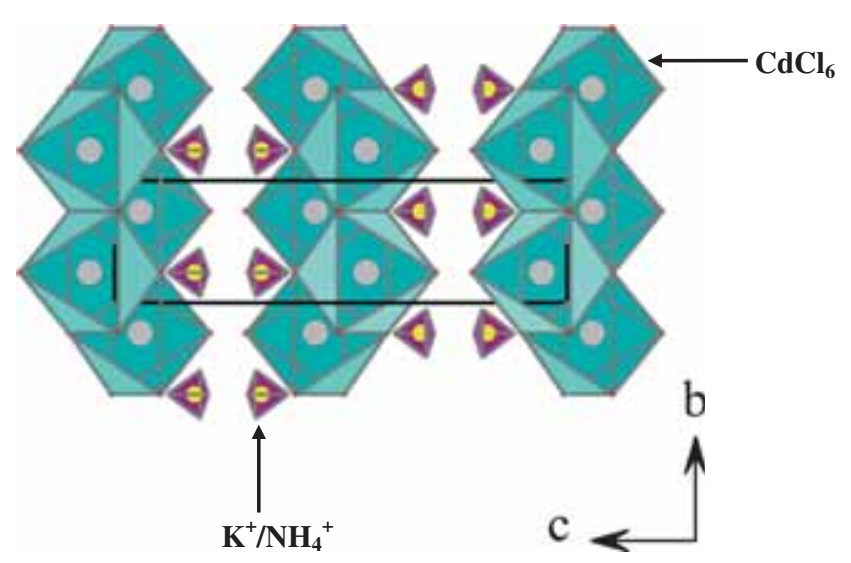

Figure 2. Projection of the $a$-axis of the atomic arrangement of $\mathrm{K}_{0.57}\left(\mathrm{NH}_{4}\right)_{0.43} \mathrm{CdCl}_{3}$ structure. 
coexistence of $\mathrm{H}$ bonding contacts $\mathrm{N}-\mathrm{H}$...Cl, which provide a linkage between cationic entities $\mathrm{NH}_{4}^{+}$and $\left[\mathrm{CdCl}_{6}\right]^{4-}$ anionic complexes.

Nitrogen or potassium atoms are coordinated nine fold by $\mathrm{Cl}$ atom neighbours. The $\mathrm{K} / \mathrm{N}-\mathrm{H}$... Cl distances range from 3.236 to $3.431 \AA$ (table 4 ).

For the second substituted compound of $\mathrm{K}_{0.25}\left(\mathrm{NH}_{4}\right)_{0.75}$ $\mathrm{CdCl}_{3}$, it has the same structure, so it may be described as consisting of double rutile-like columns of $\mathrm{CdCl}_{6}$ octahedra running along the $b$-axis (figure 3 ). The cell parameters are $a=8.9567(9) \AA, b=3.9957(4) \AA, c=14.8552(2)$ and $Z=4$. Each $\mathrm{Cd}$ atom is surrounded by six chlorine atoms in the form of a compressed ideal octahedron with distance between 2.5123(9) and 2.7142(6) $\AA$ (figure 4a). The $\mathrm{Cl}-\mathrm{Cd}-\mathrm{Cl}$ angles extend from $83.05(2)$ to $176.18(3)^{\circ}$ (table 4).

The ammonium groups are located between the chains ensuring the stability of the structure by hydrogen bonding

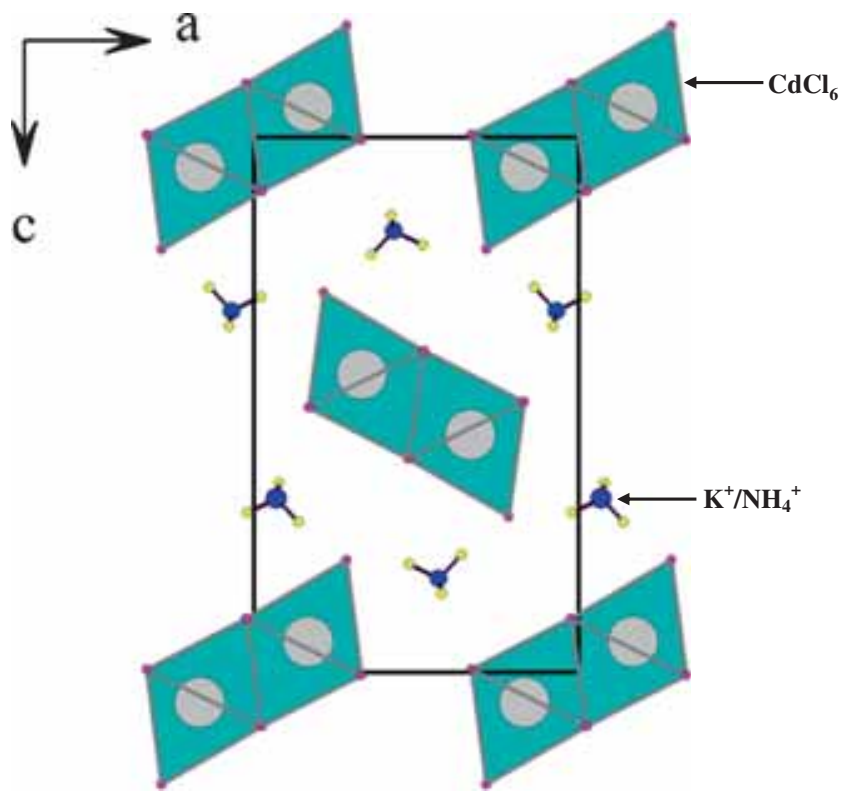

Figure 3. Projection of the $\mathrm{K}_{0.25}\left(\mathrm{NH}_{4}\right)_{0.75} \mathrm{CdCl}_{3}$ structure along the $b$-axis. contacts $(\mathrm{N}-\mathrm{H} \ldots \mathrm{Cl})$ (figure 5). The $\mathrm{K} / \mathrm{N}-\mathrm{H}$. . .Cl distances range from 3.263 to $3.433 \AA$ (table 5).

At room temperatures, the ammonium coordination polyhedra remains essentially unchanged. The groups are coordinated by nine chlorine atoms (four $\mathrm{Cl}(1)$, two $\mathrm{Cl}(2)$ and three $\mathrm{Cl}(3)$ ) (figure 6), belonging to the $\mathrm{CdCl}_{6}$ octahedral at distance between 3.2365(1) and 3.7619(1) Å (table 4).

In conclusion, at room temperature, the ammonium group $\left(\mathrm{NH}_{4}^{+}\right)$exhibits a dynamic orientational disorder, which might be similar to that observed in $\mathrm{NH}_{4} \mathrm{Cl}$ [14]. However, this ammonium disorder at room temperature influences the distortion of the octahedral $\left[\mathrm{CdCl}_{6}\right]^{4-}$.

\subsection{Ammonium rate effect on the structure}

3.2a The effect on the parameters and cell volume: With reference to the earlier studies of $\mathrm{ACdCl}_{3}$ compounds, we note that the size of the monovalent cation $\mathrm{A}^{+}$significantly affects the lattice parameters of the crystal. For this, we led to study the behaviour of these parameters with ammonium introducing into the $\mathrm{KCdCl}_{3}$ system.

This study confirms the hypothesis already established, in fact, the ammonium dependence of $a, c$ lattice parameters and the cell volume show an increasing behaviour, which indicates that the size of the $\mathrm{NH}_{4}^{+}$cation added to the network causes the cell expansion (figures 7 and 8).

From $\mathrm{K}_{0.57}\left(\mathrm{NH}_{4}\right)_{0.43} \mathrm{CdCl}_{3}$ to $\mathrm{K}_{0,25}\left(\mathrm{NH}_{4}\right)_{0.75} \mathrm{CdCl}_{3}$ compounds, we note that the hydrogen bonding $\mathrm{N}-\mathrm{H}$... Cl along the $a$ and $c$ axes becomes higher than the others (from 3.236 to $3.275 \AA$ and from 3.247 to $3.263 \AA$, respectively), so, the chlorine atoms become more and more directed to $\mathrm{NH}_{4}^{+}$ groups, which causes this behaviour after the increase of the $a$ and $c$ parameters (table 5).

The net behaviour is an increase of the unit cell volume $V$ (figure 9) as well as the $a$ and $c$ parameters with increase in the rate of ammonium in the system. This corresponds to the increases of $\mathrm{Cd}-\mathrm{Cl}$ distances, directed parallel to the $a$ and $c$ axes (table 4).

In spite of these parameters expansion, it appears that an abnormal decrease of the $b$ parameter with increase in ammonium rate. This corresponds to the decrease in $\mathrm{Cd}-\mathrm{Cl}$

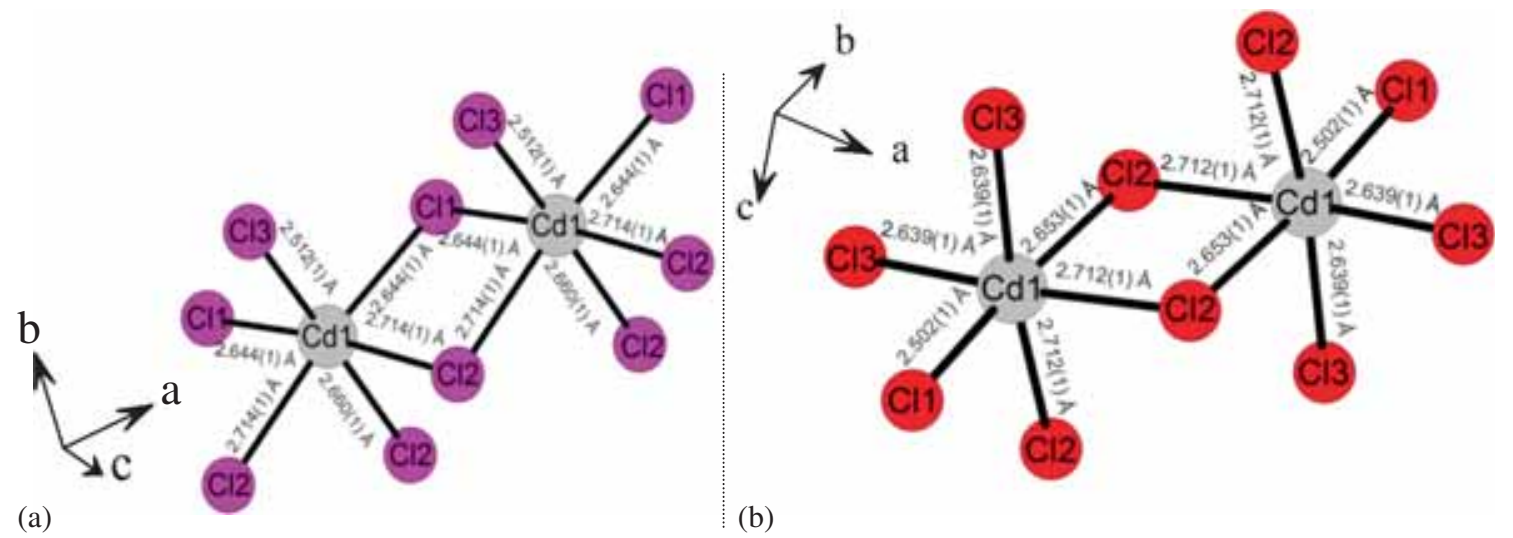

Figure 4. Environment of cadmium in (a) $\mathrm{K}_{0.25}\left(\mathrm{NH}_{4}\right)_{0.75} \mathrm{CdCl}_{3}$ and (b) $\mathrm{K}_{0.57}\left(\mathrm{NH}_{4}\right)_{0.43} \mathrm{CdCl}_{3}$. 


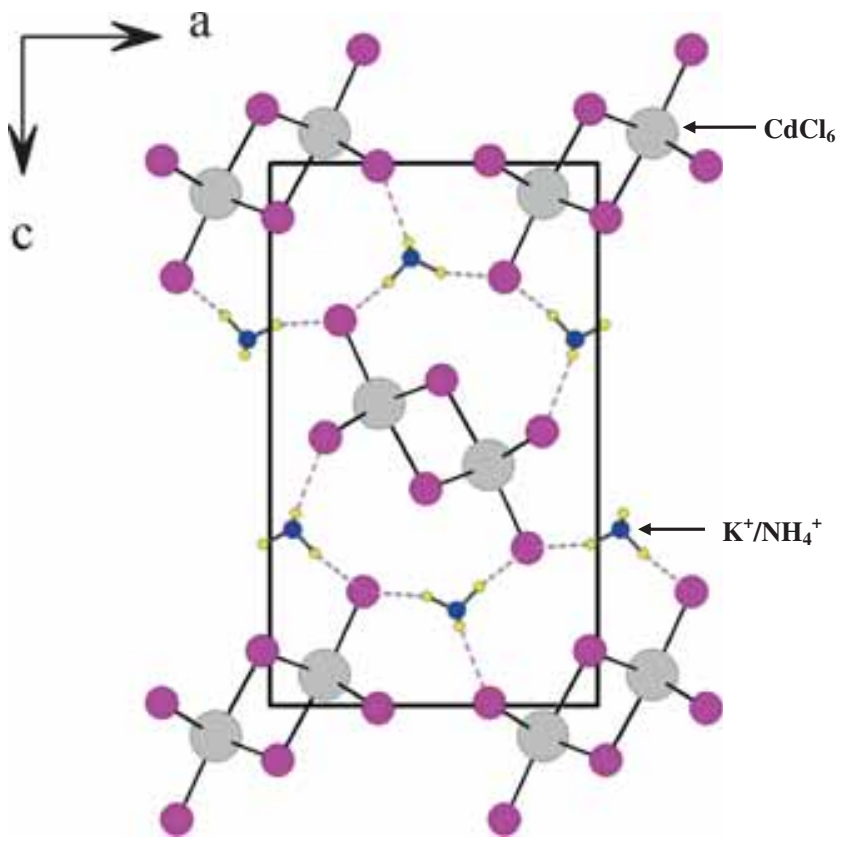

Figure 5. The structure of $\mathrm{K}_{0.25}\left(\mathrm{NH}_{4}\right)_{0.75} \mathrm{CdCl}_{3}$ projected according to the $b$-axis and including the hydrogen bonding.

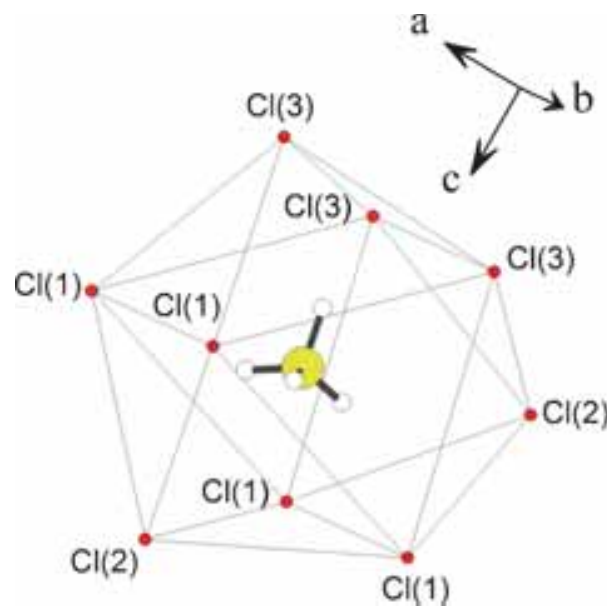

Figure 6. $\mathrm{K}^{+} / \mathrm{NH}_{4}^{+}$environment.

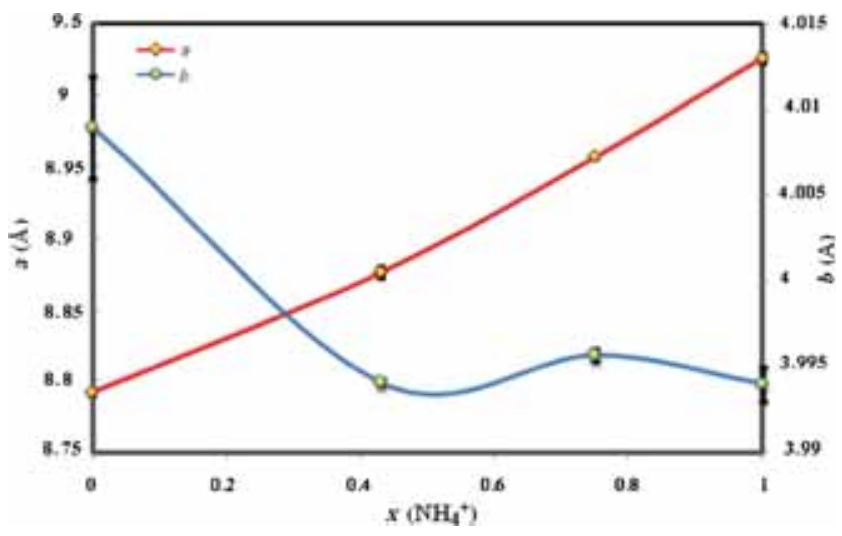

Figure 7. Percentage of ammonium dependence of the lattice parameters $a$ and $b$ for $\mathrm{K}_{x}\left(\mathrm{NH}_{4}\right)_{(1-x)} \mathrm{CdCl}_{3}$.

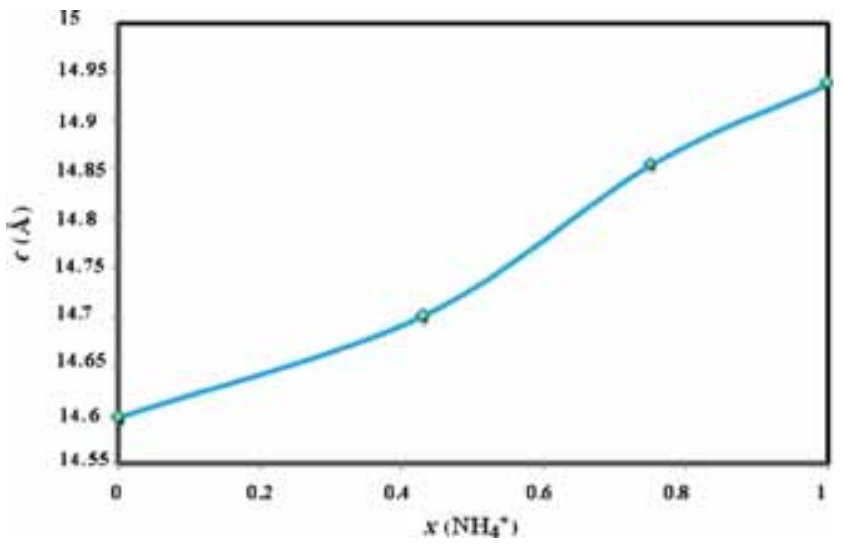

Figure 8. Percentage of ammonium dependence of the lattice parameters $c$ for $\mathrm{K}_{x}\left(\mathrm{NH}_{4}\right)_{(1-x)} \mathrm{CdCl}_{3}$.

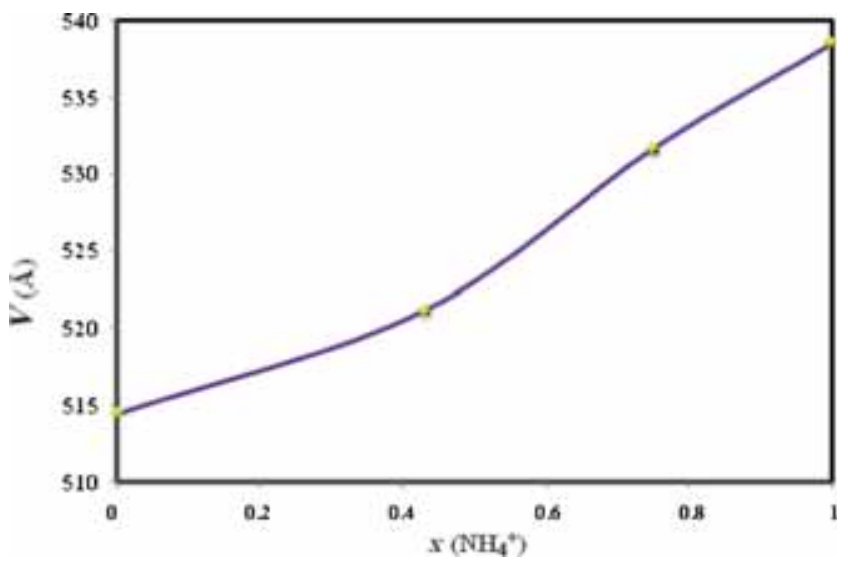

Figure 9. Percentage of ammonium dependence of the lattice volume $V \mathrm{~K}_{x}\left(\mathrm{NH}_{4}\right)_{(1-x)} \mathrm{CdCl}_{3}$.

equatorial bond distances, directed parallel to the $a$-axis (chains direction). The observed behaviour is clearly confirmed while referring to the data of table 6 .

3.2b The effect on the cation environment: Increasing rate of ammonium from $\mathrm{K}_{0.57}\left(\mathrm{NH}_{4}\right)_{0.43} \mathrm{CdCl}_{3}$ to $\mathrm{K}_{0.25}\left(\mathrm{NH}_{4}\right)_{0.75} \mathrm{CdCl}_{3}$ materials leads to a displacement of the nitrogen/potassium atoms $(0.57125(1),-0.25,0.17631(8)$ to $0.0689(2), 0.25$, $0.67525(1)$, respectively) accompanied by a relative increase in the thermal motion of $\mathrm{NH}_{4}^{+} / \mathrm{K}^{+}$groups from $0.0274(5)$ to $0.0285(7)$. This increase exhibits more dynamic orientational disorder of ammonium groups in the $\mathrm{K}_{0.25}\left(\mathrm{NH}_{4}\right)_{0.75} \mathrm{CdCl}_{3}$ compound.

\subsection{Transition characterization}

3.3a DSC measurements: In figure 10, typical DSC traces in $420-500 \mathrm{~K}$ temperature range for $\mathrm{K}_{0.25}\left(\mathrm{NH}_{4}\right)_{0.75} \mathrm{CdCl}_{3}$ and $\mathrm{K}_{0.57}\left(\mathrm{NH}_{4}\right)_{0.43} \mathrm{CdCl}_{3}$ material are shown. Two endothermic peaks at $T_{1}=454 \mathrm{~K}$ and $T_{2}=438 \mathrm{~K}$ have been observed on heating. The corresponding enthalpy changes are $\Delta H_{1}=21.25 \mathrm{~J} \mathrm{~g}^{-1}$ and $\Delta H_{2}=20.70 \mathrm{~J} \mathrm{~g}^{-1}$, respectively. 
Table 6. Comparison of $\mathrm{Cd}-\mathrm{Cl}$ bond distances.

\begin{tabular}{lcccc}
\hline & $\mathrm{KCdCl}_{3}$ & $\mathrm{~K}_{0.57}\left(\mathrm{NH}_{4}\right)_{0.43} \mathrm{CdCl}_{3}$ & $\mathrm{~K}_{0.25}\left(\mathrm{NH}_{4}\right)_{0.75} \mathrm{CdCl}_{3}$ & $\mathrm{NH}_{4} \mathrm{CdCl}_{3}[11]$ \\
\hline $\mathrm{Cd}-\mathrm{Cl}(\AA)$ & - & $2.502(1)-2.712(1)$ & $2.512(1)-2.714(1)$ & $2.513(2)-2.72(2)$ \\
\hline
\end{tabular}

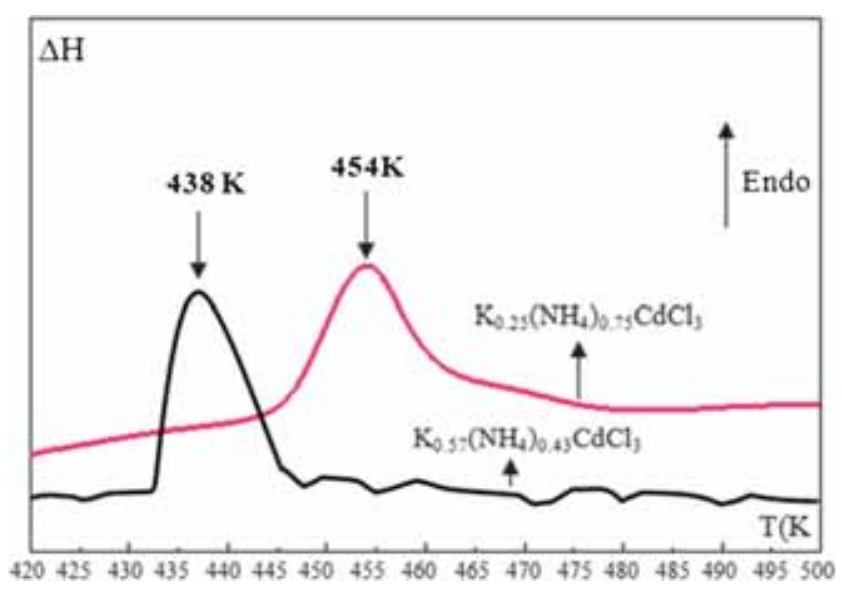

Figure 10. DSC thermogram of $\mathrm{K}_{0.25}\left(\mathrm{NH}_{4}\right)_{0.75} \mathrm{CdCl}_{3}$ in the temperature range of $420-500 \mathrm{~K}$.

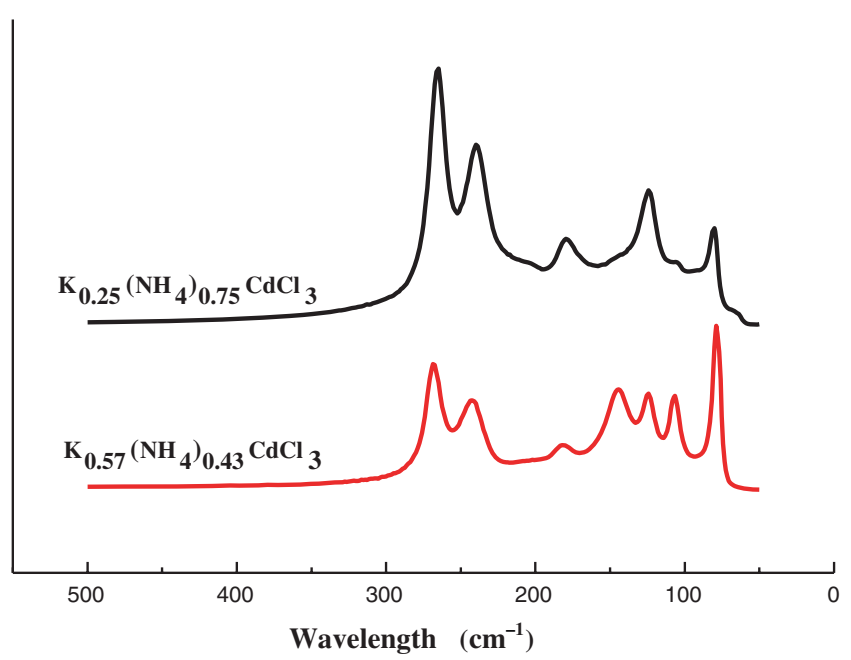

Figure 11. Raman spectra of $\mathrm{K}_{x}\left(\mathrm{NH}_{4}\right)_{(1-x)} \mathrm{CdCl}_{3}$ between 50 and $500 \mathrm{~cm}^{-1}$.

3.3b Raman spectroscopic study: Raman spectroscopic studies are realized to confirm results of the radiocrystallographic method of the mixed compounds $\mathrm{K}_{0.57}\left(\mathrm{NH}_{4}\right)_{0.43} \mathrm{CdCl}_{3}$ and $\mathrm{K}_{0.25}\left(\mathrm{NH}_{4}\right)_{0.75} \mathrm{CdCl}_{3}$. This study is restricted to the low frequency range $\left(50-500 \mathrm{~cm}^{-1}\right)$ (figure 11 and table 7$)$. The Raman bands associated with $\mathrm{K}^{+}$and $\mathrm{NH}_{4}^{+}$cations were assigned by comparison with other compounds based on cadmium [15]. The two spectra of $\mathrm{K}_{0.57}\left(\mathrm{NH}_{4}\right)_{0.43} \mathrm{CdCl}_{3}$ and $\mathrm{K}_{0.25}\left(\mathrm{NH}_{4}\right)_{0.75} \mathrm{CdCl}_{3}$ are similar.

The Raman bands observed at 80 and $105.5 \mathrm{~cm}^{-1}$ are associated with $\mathrm{K}^{+}$and $\mathrm{Cl}^{-}$translations, respectively. The band at $124.2 \mathrm{~cm}^{-1}$ corresponds to the $\mathrm{CdCl}_{2}$ libration. The
Table 7. Raman spectra of $\mathrm{K}_{0.57}\left(\mathrm{NH}_{4}\right)_{0.43} \mathrm{CdCl}_{3}$ and $\mathrm{K}_{0.25}\left(\mathrm{NH}_{4}\right)_{0.75}$ $\mathrm{CdCl}_{3}$ at room temperature ( $v$ : stretching).

\begin{tabular}{lcl}
\hline $\mathrm{K}_{0.57}\left(\mathrm{NH}_{4}\right)_{0.43} \mathrm{CdCl}_{3}$ & $\mathrm{~K}_{0.25}\left(\mathrm{NH}_{4}\right)_{0.75} \mathrm{CdCl}_{3}$ & \multicolumn{1}{c}{ Attribution } \\
\hline 78.9 & 80 & $\mathrm{~K}^{+}$translation \\
106.5 & 105.5 & ${\mathrm{Translation} \mathrm{Cl}^{-}}$ \\
124 & 124.2 & $\mathrm{CdCl}_{2}$ libration \\
144.5 & 145 & $\mathrm{NH}_{4}^{+}$translation \\
181.4 & 179.6 & $\mathrm{NH}_{4}^{+}$libration \\
242.5 & 240.5 & $v(\mathrm{CdCl})$ covalent \\
268.8 & 264.9 & $v(\mathrm{CdCl})$ \\
& & coordination \\
\hline
\end{tabular}

Table 8. IR spectra at room temperature of $\mathrm{K}_{0.57}\left(\mathrm{NH}_{4}\right)_{0.43} \mathrm{CdCl}_{3}$ and $\mathrm{K}_{0.25}\left(\mathrm{NH}_{4}\right)_{0.75} \mathrm{CdCl}_{3}$ ( $\delta$ : deformation).

\begin{tabular}{lcc}
\hline $\mathrm{K}_{0.57}\left(\mathrm{NH}_{4}\right)_{0.43} \mathrm{CdCl}_{3}$ & $\mathrm{~K}_{0.25}\left(\mathrm{NH}_{4}\right)_{0.75} \mathrm{CdCl}_{3}$ & Assignment \\
\hline 558 & 558 & $\begin{array}{c}\mathrm{H}_{2} \mathrm{O} \text { libration } \\
\text { in } \mathrm{KBr}\end{array}$ \\
1395 & 1395 & $\delta_{\text {as }}\left(\mathrm{NH}_{4}^{+}\right)$ \\
1625 & 1625 & $\delta_{\mathrm{s}}\left(\mathrm{NH}_{4}^{+}\right)$ \\
3156 & 3153 & $\delta_{\mathrm{s}}\left(\mathrm{NH}_{4}^{+}\right)$ \\
3556 & 3497 & $\mathrm{H}_{2} \mathrm{O} \mathrm{libration}$ \\
& & in $\mathrm{KBr}$ \\
\hline
\end{tabular}

libration mode of $\mathrm{NH}_{4}^{+}$appears at $145 \mathrm{~cm}^{-1}$, where the translational mode appears at $179.6 \mathrm{~cm}^{-1}$. The relatively most intense band at $282 \mathrm{~cm}^{-1}$ and the shoulder at $247 \mathrm{~cm}^{-1}$ correspond to $v \mathrm{CdCl}$ stretching. The presence of two modes of $\mathrm{Cd}-\mathrm{Cl}$ vibrations which differs in magnitude and frequency, supports the radiocrystallographic results concerning the octahedral coordination of the cadmium and the coexistence of two types of $\mathrm{Cd}-\mathrm{Cl}$ bondings: strong covalent bonds and coordination bonds.

3.3c IR spectroscopy investigation: At room temperature, the frequencies of the observed two phases are listed in table 8 . The IR bands associated with the $\mathrm{NH}_{4}^{+}$group were assigned by comparison with the spectra of $\mathrm{NH}_{4} \mathrm{CdCl}_{3}$ [16]. The bands observed at 3497 and $558 \mathrm{~cm}^{-1}$ are characteristic of water molecules from KBr. The band observed at 3153 $\mathrm{cm}^{-1}$ is due to $v\left(\mathrm{NH}_{4}^{+}\right)$stretching modes. The symmetric and asymmetric bending vibrations of $\mathrm{NH}_{4}^{+}$appear in two bands at 1625 and $1395 \mathrm{~cm}^{-1}$.

The spectral evolution with increasing temperature is shown in figures 12 and 13. The transitions are clearly characterized. To gain more information on the crystal dynamics and to determine the nature of the high temperature phase 


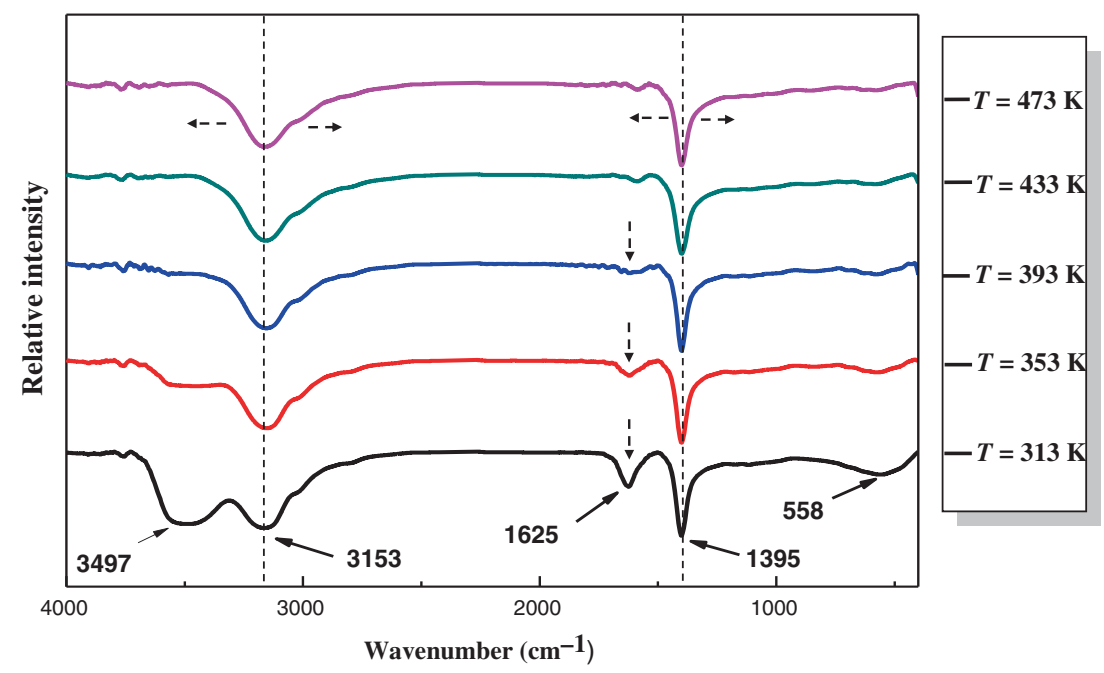

Figure 12. IR spectra at different temperatures of $\mathrm{K}_{0.57}\left(\mathrm{NH}_{4}\right)_{0.43} \mathrm{CdCl}_{3}$.

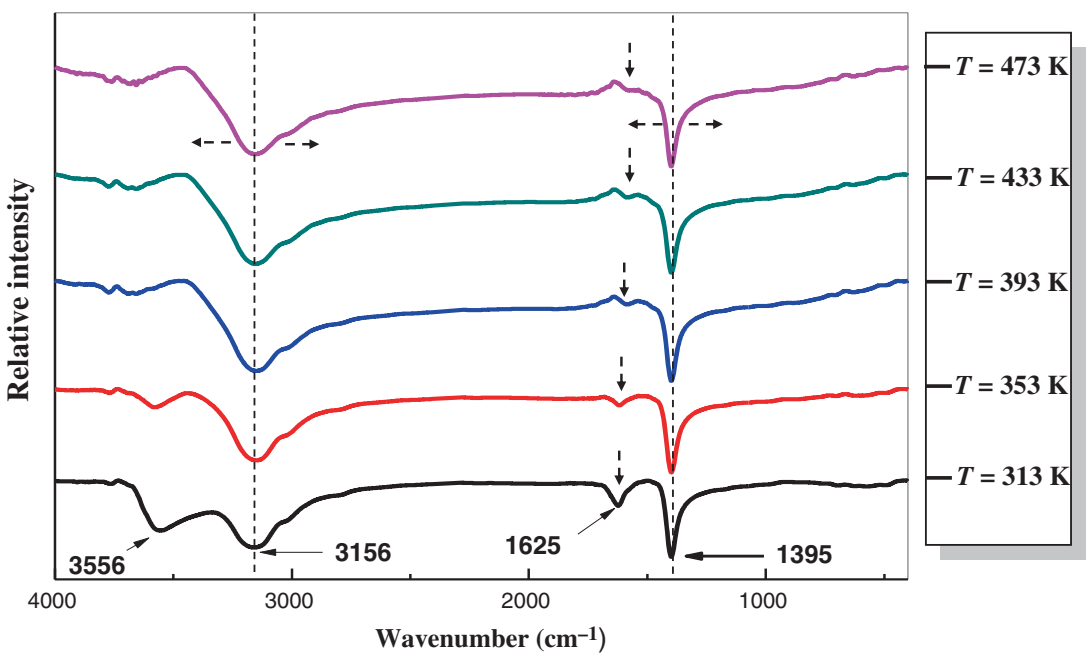

Figure 13. IR spectra at different temperatures of $\mathrm{K}_{0.25}\left(\mathrm{NH}_{4}\right)_{0.75} \mathrm{CdCl}_{3}$.

transitions, we have undertaken an IR study between 303 and $463 \mathrm{~K}$.

From these curves, it could be seen that at about $400 \mathrm{~K}$, changes in the IR band are the characteristics of the ammonium groups. The spectral changes concern the internal vibrations of $\mathrm{NH}_{4}^{+}$tetrahedra. This transition is defined by the following changes:

(1) The band at $3153 \mathrm{~cm}^{-1}$ increases in intensity and increases in halfwidth.

(2) Disappearance of the librational modes of $\mathrm{NH}_{4}^{+}$cations at $1625 \mathrm{~cm}^{-1}$ indicate the large dynamic motion of $\mathrm{NH}_{4}^{+}$at high temperature.

(3) The halfwidth of the band at $1395 \mathrm{~cm}^{-1}$ increases.

DSC measurements, infrared and raman spectra show that the title compounds probably undergo an orientational 'order-disorder' phase transition of $\mathrm{NH}_{4}^{+}$tetrahedra at $454 \mathrm{~K}$ for $\mathrm{K}_{0.25}\left(\mathrm{NH}_{4}\right)_{0.75} \mathrm{CdCl}_{3}$ and at $438 \mathrm{~K}$ for $\mathrm{K}_{0.57}\left(\mathrm{NH}_{4}\right)_{0.43} \mathrm{CdCl}_{3}$.
It follows that the increase in temperature probably does not affect the structural arrangement, but it leads to an 'order-disorder' phase transition.

3.3d Dielectric study: The dielectric study is an important source of valuable information about conduction processes. To obtain more information on the crystal dynamics, we have undertaken a dielectric study between 300 and $550 \mathrm{~K}$ in the frequency range of $100 \mathrm{~Hz}-5 \mathrm{MHz}$ for $\mathrm{K}_{0.25}\left(\mathrm{NH}_{4}\right)_{0.75} \mathrm{CdCl}_{3}$.

Figures 14 and 15 illustrate respectively, the temperature dependence of the real $\varepsilon_{\mathrm{r}}^{\prime}$ part of the complex electric and dielectric losses $\tan \delta$. From these curves, we can observe an anomaly at about $454 \mathrm{~K}$. This transition can be attributed to the 'order-disorder' phase transition, which probably characterizes the motion of a rapid $\mathrm{NH}_{4}^{+}$reorientation and $\mathrm{H}^{+}$ diffusion. However, if the temperature is raised, the reorientation of $\mathrm{NH}_{4}^{+}$ions becomes more excited and the protons jump over the potential barrier [17]. 


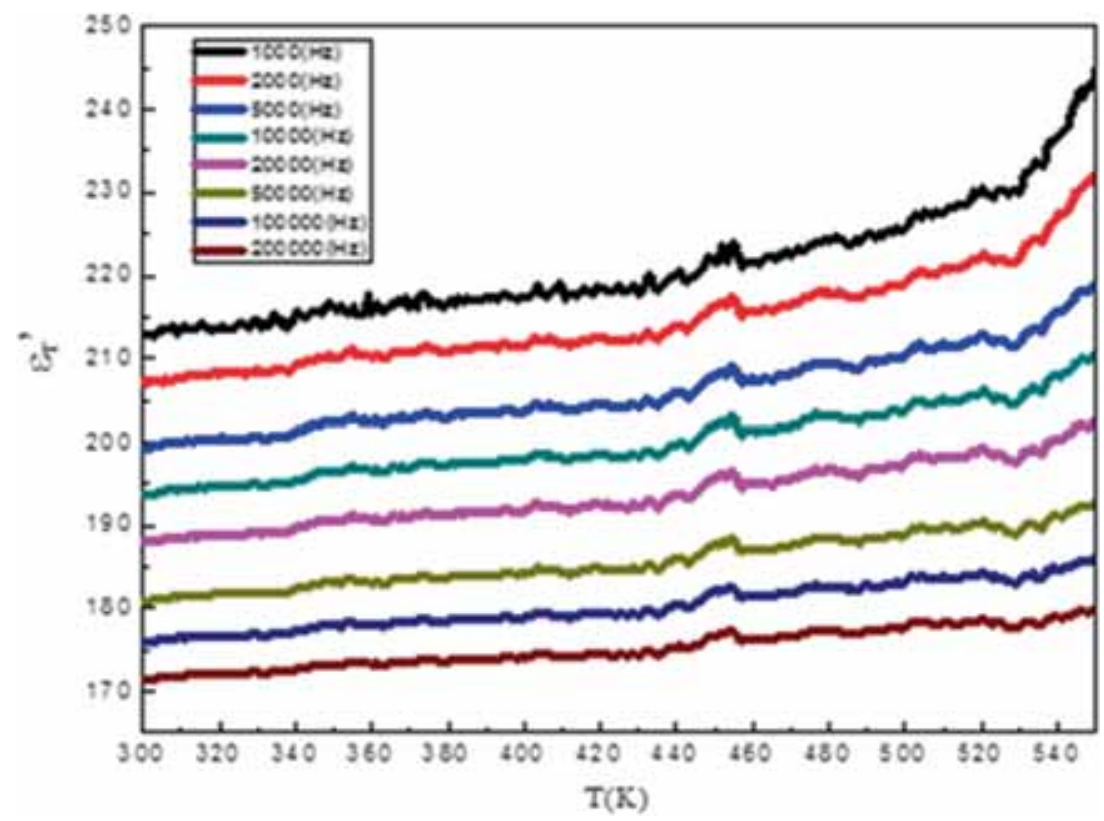

Figure 14. Temperature dependence of $\varepsilon_{r}^{\prime}$ at different frequencies for $\mathrm{K}_{0.25}\left(\mathrm{NH}_{4}\right)_{0.75} \mathrm{CdCl}_{3}$.

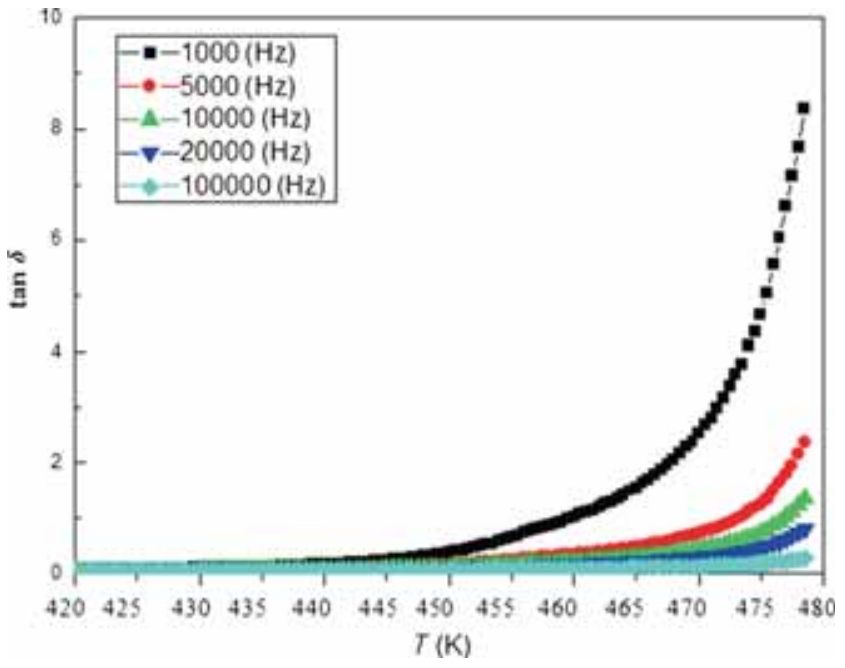

Figure 15. Variation of the dielectric loss factor $(\tan \delta)$ as a function of temperature at various frequencies for $\mathrm{K}_{0.25}\left(\mathrm{NH}_{4}\right)_{0.75} \mathrm{CdCl}_{3}$.

Dielectric studies confirm the presence of the same anomaly that has been observed by thermal analysis using the DSC measurements. We can conclude that the phase transition is probably governed by an order-disorder mechanism.

\section{Conclusions}

The two new mixed compounds, $\mathrm{K}_{0.57}\left(\mathrm{NH}_{4}\right)_{0.43} \mathrm{CdCl}_{3}$ and $\mathrm{K}_{0.25}\left(\mathrm{NH}_{4}\right)_{0.75} \mathrm{CdCl}_{3}$, were crystallized in the orthorhombic system with the space group Pnma at room temperature $293 \mathrm{~K}$. The crystal structure of the title compound is characterized by $\mathrm{CdCl}_{6}$ octahedra linked in endless chains running along the $b$-axis. The potassium or ammonium cations are inserted between these chains ensuring the stability of the structure by ionic and hydrogen bonding contacts $\mathrm{N}-\mathrm{H}$...Cl.

From the study of the influence of substitution, we concluded that the ammonium introduction into the network of $\mathrm{KCdCl}_{3}$ does not affect structural arrangement, but it leads to an increase of the $a, c$ parameters and $V$ cell volume. However, we observe a decrease of the parameter $b$.

This study shows that the title compounds, $\mathrm{K}_{0.57}\left(\mathrm{NH}_{4}\right)_{0.43} \mathrm{CdCl}_{3}$ and $\mathrm{K}_{0.25}\left(\mathrm{NH}_{4}\right)_{0.75} \mathrm{CdCl}_{3}$, undergoes an orientational 'order-disorder' phase transition of $\mathrm{NH}_{4}^{+}$ tetrahedra at about 454 and $438 \mathrm{~K}$ as determined by electrical properties, DSC and IR vs. temperature. This can be explained by a disordering of the $\mathrm{NH}_{4}^{+}$groups and a distortion of the $\mathrm{CdCl}_{6}$ octahedra in the high temperature phases.

\section{Acknowledgements}

The crystal data collection of the title compound was done in the Department of Chemistry, Faculty of Sciences of Sfax, University of Sfax, BP 1171, 3038 Sfax, Tunisia. We are grateful to Abdelhamid Ben Salah who supervised this experiment. The Raman spectrum was done in "Laboratory of Ferroelectric materials, Faculty of Sciences of Sfax, University of Sfax, BP 1171, 3038 Sfax, Tunisia". We are grateful to Hamadi Khemkhem who supervised this experiment.

\section{References}

[1] Fischer M 1982 J. Phys. Chem. Solids 43673

[2] Brasseur H and Pauling L 1938 J. Amer. Chem. Soc. 602886 
[3] Chang J R, Pherson G L and Atwood J L 1975 Inorg. Chem. 143079

[4] Hoppe R 1984 Z. Anorg. Allg. Chem. 51492

[5] Sakida S and Kawamoto Y 2002 J. Phys. Chem. Solids 63151

[6] Lim A R and Jeong S Y 2005 J. Solid State Chem. 1783095

[7] Li T-I, Stucky G D and McPherson G L 1973 Acta Crystallogr. B 291330

[8] Tanaka H 1990 J. Magn. Magn. Mater. 90\&91 251

[9] Valiente R, Wenger O S and Gudel H U 2001 Phys. Rev. B 63 165102

[10] Kakurai K, Nakajima K, Endoh Y, Endoh K, Iio K, Tanaka H and Steiner M 1992 J. Magn. Magn. Mater. 104-107 857
[11] Brisi C 1952 Ann. Chim. 42356

[12] Sheldrick G M 1986 SHELXS97, Program for the Refinement of Crystal Structures (Germany: University of Gottingen).

[13] Perry C H and Lowdes R P 1969 J. Chem. Phys. 513648

[14] Sheldrick G M 1997 SHELXS9, Program for the Refinement of Crystal Structures (Germany: University of Gottingen).

[15] Loukil M, Kabadou A, Salles Ph and Ben Salah A 2004 Chem. Phys. 300247

[16] Rolies M M and De Ranter C J 1978 Acta Crystallogr. B 34 3057

[17] Kabadou A, Walha S, Mnif M, Ben Hassen R and Ben Salah A 1999 Solid State Ion. 122263 